\title{
RADIOCARBON DATING OF FUGENDAKE VOLCANO IN UNZEN, SW JAPAN
}

\author{
Sheng $\mathrm{Xu}^{1,2} \bullet$ Hideo Hoshizumi ${ }^{3} \cdot \mathrm{Kozo}_{\mathrm{Uto}^{3}} \bullet$ Stewart P H T Freeman $^{1}$ \\ ABSTRACT. This article presents new radiocarbon ages for the lavas, pyroclastic flow, and lahar deposits that originated \\ from the Fugendake and Mayuyama volcanoes of the Younger Unzen Volcano, SW Japan. Nine charcoal samples were col- \\ lected from the lavas and pyroclastic flow deposits, and 17 soil samples from the underlying volcanic-related products. This \\ data set, together with previously published ages (thermoluminescence, $\mathrm{K}-\mathrm{Ar}$, fission track, and ${ }^{14} \mathrm{C}$ ), yielded new informa- \\ tion about the timing of Late Pleistocene eruptions and an improved understanding of the evolution of the Fugendake and \\ Mayuyama volcanoes. Fugendake Volcano started to build within the scar of Myokendake around 29 cal ka BP, and its erup- \\ tion products spread over the flank of Myokendake. The remarkable eruptions of Fugendake Volcano included the lava and \\ pyroclastic flow deposits around 22, 17, 12, and $4.5 \mathrm{cal}$ ka BP. Subsequent historical eruptions occurred in AD 1663, 1792, \\ and 1991-1995. Developed on the eastern extension of Fugendake Volcano, Mayuyama Volcano was active during the build- \\ ing stage of Fugendake at $4.5 \mathrm{cal} \mathrm{ka}$ BP. This study also identified a pumice eruption at $\sim 10 \mathrm{ka}$ and 2 volcanic-related lahar \\ deposits around 1.6 and $0.7 \mathrm{ka}$, which need to be addressed in future research.
}

\section{INTRODUCTION}

Unzen Volcano is situated in an active graben, approximately $70 \mathrm{~km}$ west of the volcanic front of SW Japan (Figure 1). It began $\sim 500 \mathrm{ka}$ ago, and the latest eruption occurred in 1991-1995. The composite volcanic edifice can be subdivided into the Older (500-150 ka) and Younger Unzen volcanoes (150-0 ka). The latter comprises the Nodake, Myokendake, Fugendake, and Mayuyama volcanoes (Watanabe and Hoshizumi 1995; Hoshizumi et al. 1999). Geological observation suggested that Fugendake Volcano was built within the horseshoe-shaped scar of Myokendake, and its eruption products spread over the flank of Myokendake (Figure 2). Nodake is an isolated volcanic center adjacent to Myokendake. Mayuyama is completely isolated from these 3 volcanoes.

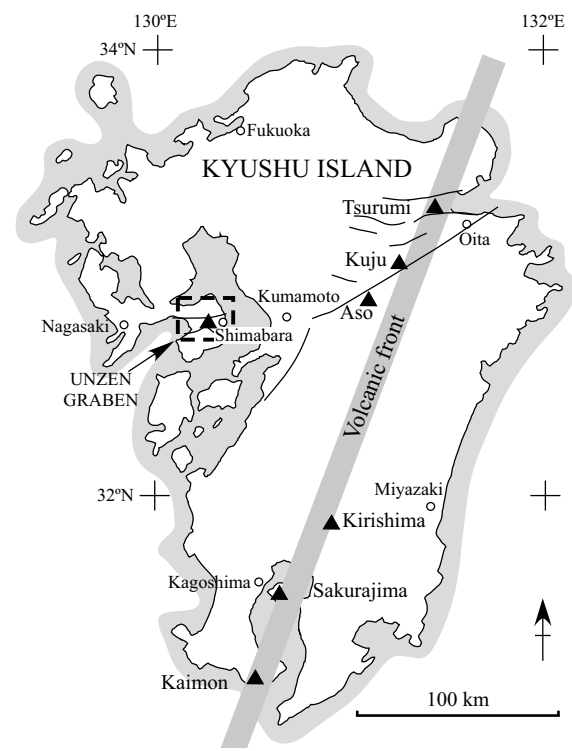

Figure 1 Location of Unzen Volcano. Solid triangles denote active volcanoes. Those distributed along the volcanic front are typical island-arc type volcanoes caused by the Philippine Sea plate subducting beneath SW Japan, while the Unzen volcanoes are considered to relate to the active graben development in last $500 \mathrm{ka}$.

\footnotetext{
${ }^{1}$ Scottish Universities Environmental Research Centre, East Kilbride G75 0QF, United Kingdom.

${ }^{2}$ JAEA Tono Geoscience Center, Toki, Gifu 509-5102, Japan. Corresponding author. Email: s.xu@suerc.gla.ac.uk.

${ }^{3}$ Geological Survey of Japan, Tsukuba, Ibaraki 305-8567, Japan.
}

(C) 2013 by the Arizona Board of Regents on behalf of the University of Arizona

Proceedings of the 21st International Radiocarbon Conference edited by A J T Jull \& C Hatté

RADIOCARBON, Vol 55, Nr 2-3, 2013, p 1850-1861 


\section{S Xu et al.}

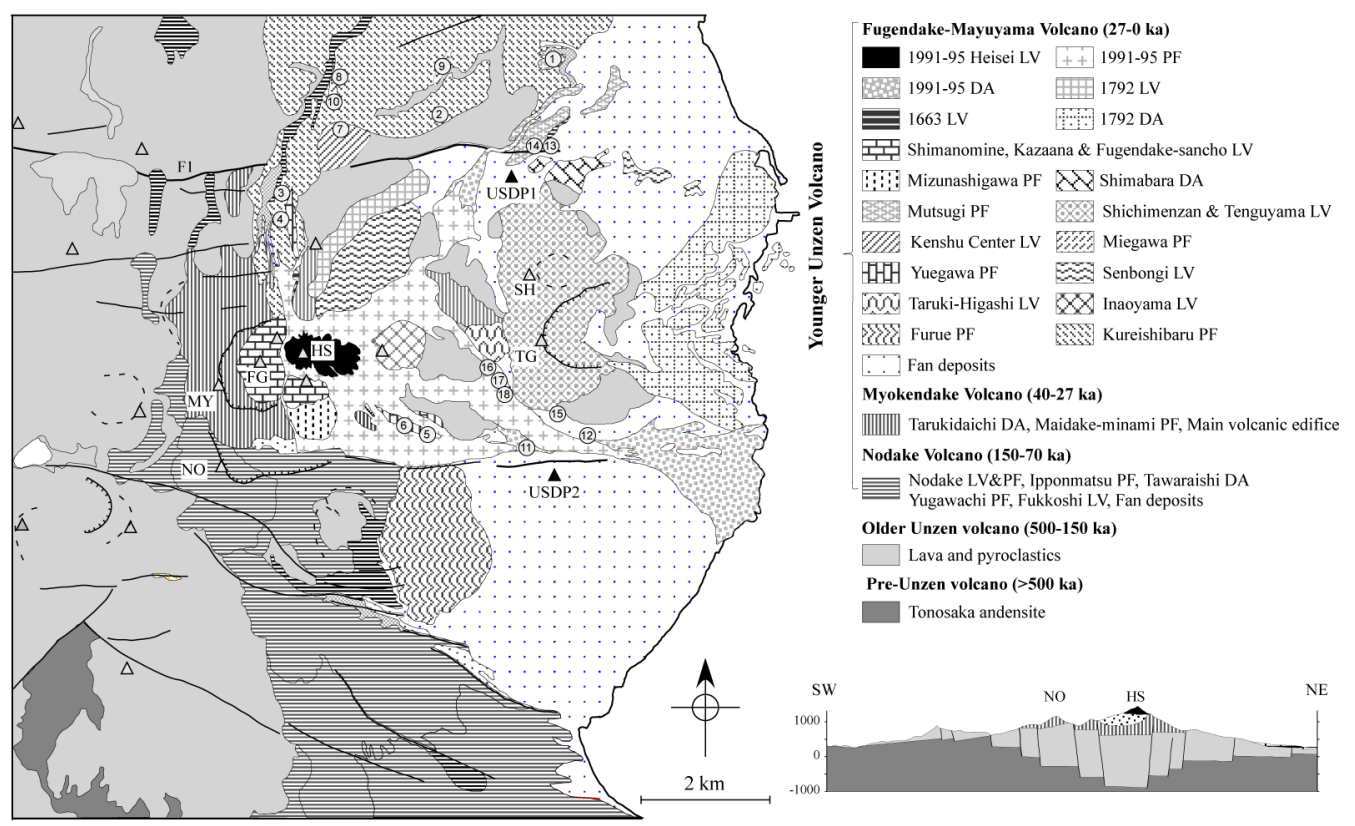

Figure 2 Geological map of Unzen Volcano modified from Watanabe and Hoshizumi (1995). A series of faults E-W in direction comprise Unzen graben (F1: Chichiwa fault). Unzen scientific drilling project boreholes (USDP-1 and 2) shown with solid triangles are located in the northern and central graben, respectively. Sample locations listed in Table 1 are indicated by open circles with numbers. Mountains: $\mathrm{FG}=$ Fugendake; $\mathrm{HS}=$ Heisei-Shinzan; $\mathrm{MY}=$ Myokendake; $\mathrm{NO}=\mathrm{Nodake}$;H = Schichimenzan; TG = Tenguyama.

Unzen Volcano developed in the EW-trending tectonic graben within the back of the Ryuku arc in SW Japan. Synchronous development of nested normal faults during the growth of Unzen Volcano has resulted in the periodic subsidence of the main edifice and the accumulation of thick volcanic products down to $\sim 1 \mathrm{~km}$ below sea level. As a result, no stratigraphic relationships between the volcanic products can be observed directly. The present stratigraphy of the eruption products was therefore established roughly by 2 locally exposed key-mark tephras (Kikai-Ah ash: $7.3 \mathrm{cal} \mathrm{ka} \mathrm{BP,} \mathrm{and}$ Aira-Tn ash: 29 cal ka BP, both of which originated from southern Kyushu; Machida and Arai 1983; Okuno et al. 1997, 1998) and sparsely accumulated radiometric ages using K-Ar (Ono et al. 1992; Watanabe et al. 1993; Hoshizumi et al. 1995, 1999), fission track (FT, Danhara et al. 1993), thermoluminescence (TL, Takashima and Watanabe 1994; Shimao et al. 1999; Yamagata et al. 2004; Moriyasu et al. 2008), and radiocarbon dating (Kobayashi and Kato 1986; Kobayashi and Nakada 1991; Hoshizumi et al. 1999; Xu et al. 2004; Ozeki et al. 2005). It is well known that the data from radiogenic methods other than ${ }^{14} \mathrm{C}$ dating are typically imprecise for young materials. However, the scarcity of charcoal in Unzen Volcano made it difficult to apply the ${ }^{14} \mathrm{C}$ method. Kobayashi and Nakada (1991) dated burned trunk pieces scattered in the Kureishibaru pyroclastic flows with ages of 14 and $19 \mathrm{ka} \mathrm{BP}$, and a ${ }^{14} \mathrm{C}$ age of $4.5 \mathrm{ka}$ BP from 2 burned trunks in the Mizunashigawa pyroclastic flow. An average ${ }^{14} \mathrm{C}$ age $4.3 \mathrm{ka}$ BP from 3 charcoals from the Mutsugi pyroclastic flow deposits has been obtained (Kobayashi and Kato 1986; Hoshizumi et al. 1999; Ozeki et al. 2005). Obviously, these data are not enough to document the eruption history of the Younger Unzen Volcano. Moreover, the scarcity of charcoal in Unzen Volcano required us to examine the ${ }^{14} \mathrm{C}$ dates on the buried soil organic carbon of bulk sample underlying the volcanic eruption products instead, as the age of buried soil can potentially represent the accumulation time of overlying materials that quickly accumulated (Orlova and Panychev 1993; Okuno et al. 1997; Okuno and Nakamura 2003). 
${ }^{14} \mathrm{C}$ Dating of Fugendake Volcano in Unzen, SW Japan

\section{MATERIALS AND METHODS}

Charcoal and soil samples were used for ${ }^{14} \mathrm{C}$ dating in this study. Sampling locations are given in Table 1 and Figure 2. Charcoals were collected from the volcanic lava, pyroclastic flow, and pumice deposits of the Fugendake and Mayuyama volcanoes. Soil samples were collected from the topmost $(<2 \mathrm{~cm})$ soil underlying the volcanic-related products including lava, pyroclastic flow, ash, and lahar flow deposits. Care was always taken to minimize any effect from the roots of modern plants. Soil samples were first sieved and fractions with $<106-\mu \mathrm{m}$ mesh were used. Charcoal and soil samples were chemically treated by routine acid-alkali-acid (AAA) methodology. After the chemical treatment, soil organic carbon was further separated into humic acid and humin fractions. The detailed procedure of chemical treatment, graphite target preparation, $\delta^{13} \mathrm{C}$ determination, and ${ }^{14} \mathrm{C}$ AMS measurement has been described previously (Xu and Zheng 2003).

\section{RESULTS AND DISCUSSION}

Conventional ${ }^{14} \mathrm{C}$ and $\delta^{13} \mathrm{C}$ results for the charcoal and soil samples are listed in Table 1 . The ${ }^{14} \mathrm{C}$ ages were corrected for isotope fractionation using $\delta^{13} \mathrm{C}$ values and blanks. The stated uncertainties $(1 \sigma)$ of ${ }^{14} \mathrm{C}$ ages include both the statistical uncertainty and the reproducibility of the standards and blanks. To compare with other radiometric dating methods, Table 1 also lists the calibrated age ranges $(2 \sigma)$ and median ages calculated using the OxCal v 4.1 program (Bronk Ramsey 2009) and the IntCal09 curve (Reimer et al. 2009). Duplicate analysis was done on 2 charcoal samples (JNC1421 vs. 1427, and JNC1431 vs. 1934), and a humic acid fraction of a humic soil sample (JNC1699 vs. 1708). Their $\delta^{13} \mathrm{C}$ values and ${ }^{14} \mathrm{C}$ ages were consistent within the error margin.

\section{Validity of ${ }^{14} \mathrm{C}$ Dating Buried Soils}

In alluvial and flood deposits, where soil burial occurs relatively quickly, and where the thickness of overlying sediments is sufficiently great to remove the buried soil from the zone of penetration of the present root system, ${ }^{14} \mathrm{C}$ dates of soil organic fraction have been declared theoretically valid (Orlova and Panychev 1993; Braitseva et al. 1993; Madeira et al. 1997; Goto et al. 2011). In volcanic areas, soil burial is usually quick and typically the thickness of overlying volcanic deposits (pyroclastic, lava, and lahar flow deposits) are sufficiently great. Thus, the physical structure of volcanic deposits preserves soil organics and prevents soil organic matter movement along the depth profile. We therefore consider that ${ }^{14} \mathrm{C}$ dates of soil immediately below the volcanic deposits to be representative of the time when the deposits covered the soil, namely, eruption and/or accumulation age. In practice, ${ }^{14} \mathrm{C}$ dates from soil below the tephra layers in southern Kyushu Island showed good agreement with one other and are also consistent with the dates for charcoal and historical dates (Okuno et al. 1997, 1998; Okuno and Nakamura 2003). However, ${ }^{14} \mathrm{C}$ dating of the bulk soil organic matter is always a problematic subject, mainly due to the complexity of the soil formation and to the variable contamination from different sources. Many researchers have qualitatively explained the age discrepancy between organic fractions of soil (e.g. Scharpenseel 1979; Orlova and Panychev 1993; Martin and Johnson 1995). Although traditionally the humic acid fraction was thought to yield younger ${ }^{14} \mathrm{C}$ ages than humin fraction in routine AAA chemical treatment, later literature has questioned this inference (e.g. Head et al. 1989; Hamnond et al. 1991; Orlova and Panychev 1993). Thus, the question still arises of which fraction age is more reliable in the case of an age difference in soil organic matter fractions. It is well agreed that any fractions should contain relatively high organic carbon (Scharpenseel 1979). Okuno et al. (1997) also discussed the reliability of a soil sample with carbon content and $\mathrm{C} / \mathrm{N}$ ratios and concluded that a high $\mathrm{C} / \mathrm{N}$ ratio is one of the promising indications of reliable ${ }^{14} \mathrm{C}$ dates. Based on these arguments, ${ }^{14} \mathrm{C}$ ages of humic acid and humin fractions were considered and compared in this study. 
SXu et al.

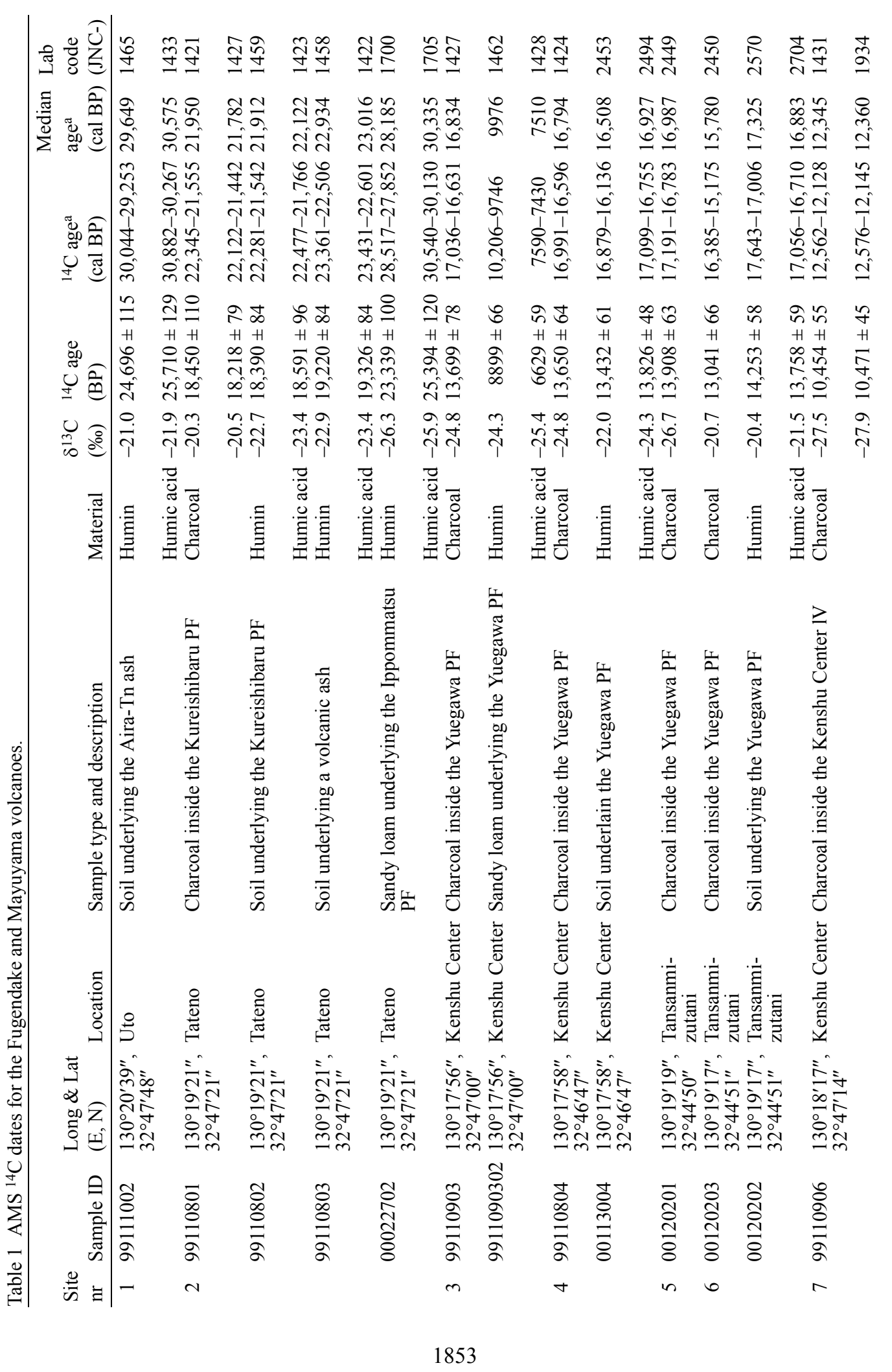


${ }^{14} \mathrm{C}$ Dating of Fugendake Volcano in Unzen, SW Japan

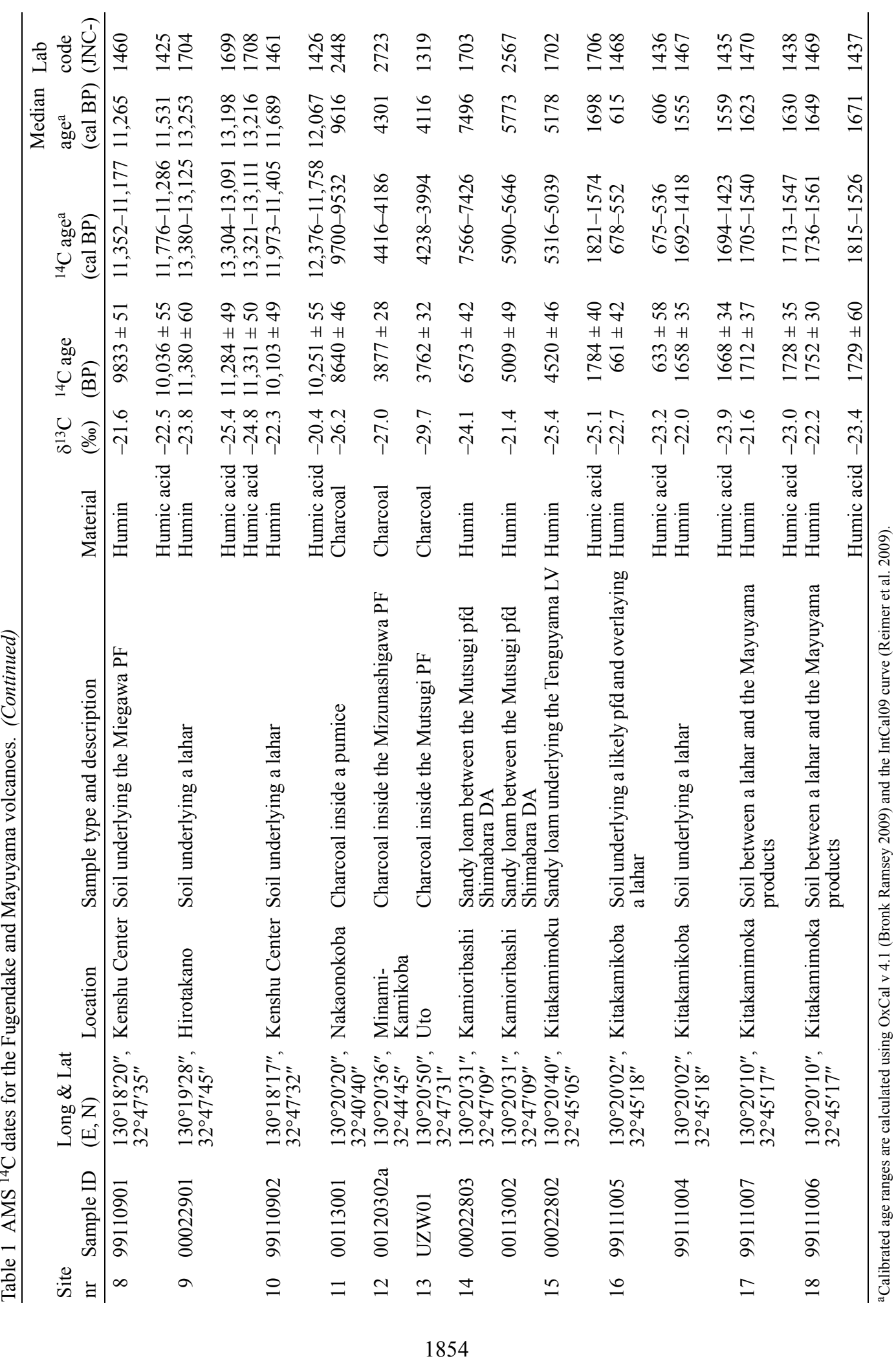




\section{SXu et al.}

Table 1 shows that all humic soil samples gave coeval ${ }^{14} \mathrm{C}$ dates on the humic acid and humin fraction within the $2 \sigma$ error margin in each soil horizon. Aira-Tn ash is widespread co-ignimbrite ash-fall deposits from Aira caldera of 29 ka cal BP (Okuno 2002; Okuno and Nakamura 2003). As shown for site 1 (Figures 2 and 3 ), the ${ }^{14} \mathrm{C}$ ages of both soil fractions underlying the Aira-Tn ash, 2930 cal ka BP (JNC1433 and 1465), are in good agreement with the nominal value. In the soil-volcanic products profile where charcoal is available, the soil ${ }^{14} \mathrm{C}$ dates are essentially identical to the charcoal ages. This finding strongly supported that the age of both organic fractions of buried humic soil can potentially represent accumulation time of overlying materials that have quickly accumulated (Orlova and Panychev 1993; Okuno et al. 1997).

It should be noted, however, that sandy loam samples had large age discrepancies between organic fractions (i.e. JNC1700 vs. 1705 , JNC1462 vs. 1428 , JNC1702 vs. 1706). The sandy loam underlying the Ippommatsu pyroclastic flow deposits dated to 23,339 $\pm 100 \mathrm{BP}$ (JNC1700) and $25,394 \pm 120 \mathrm{BP}(\mathrm{JNC} 1705)$ for the humin and humic acid fraction, respectively. As the Ippommatsu pyroclastic flow deposits were covered by Aira-Tn ash (29 cal BP) in the stratigraphic section, the soil underlying the Ippommatsu pyroclstic flow deposits should be significantly older than the Aira-Tn ash. However, this is not the case. A thin sandy loam layer $(\sim 10 \mathrm{~cm})$ was observed underlying the Tenguyama lavas (site 15). This sample gave ages of $4520 \pm 46 \mathrm{BP}$ (JNC1702) and $1784 \pm 40 \mathrm{BP}$ (JNC1706) for the humin and humic acid fraction, respectively. Obviously, although the humin age is consistent with the TL date for the Tenguyama lava $(4.1 \pm 0.8 \mathrm{ka}$, Yamagata et al. 2004), it is significantly older than humic acid fraction, which makes it difficult to justify the validity of the data. Moreover, no humic acid fractions can be extracted from the sandy loam samples (JNC1703 and 2567) collected in different times from the top of a $\sim 50$-cm-thick sandy loam layer between the Mutsugi pyroclastic flow deposit and the Shimabara debris avalanche (site 14). The ${ }^{14} \mathrm{C}$ ages of the humin fraction of 2 samples were $6573 \pm 42 \mathrm{BP}(\mathrm{JNC} 1703)$ and $5009 \pm 49 \mathrm{BP}$ (JNC2567). These discrepant dates were significantly older than the age of the overlying Mutsugi pyroclastic flow deposits whose age is most likely around $4 \mathrm{ka} \mathrm{BP}$, as referred from the adjacent sites (Kobayashi and Kato 1986). These observations therefore strongly suggest that any fractions of sandy loam sample are not reliable material for ${ }^{14} \mathrm{C}$ dating of volcanic eruptions. Although the details of the mechanism are not yet clear, a low carbon content in sandy loam seems to be more sensitive to contamination from modern carbon, as observed elsewhere (Scharpenseel 1979; Okuno et al. 1997). With these considerations, we can interpret the data in Table 1 and discuss the eruption age of the Fugendake and Mayuyama volcanoes using ${ }^{14} \mathrm{C}$ dates obtained from charcoal and/or humic soil that has coeval humic acid and humin ages.

\section{Radiocarbon Dating of the Fugendake-Mayuyama Volcano}

Fugendake Volcano was developed inside and outside of the Myokendake scar (Figure 2). Field investigations divided the Fugendake Volcano into several lava flows (L), lava domes, and pyroclastic flow deposits (PF), and 1 debris-avalanche (DA) deposit (Watanabe and Hoshizumi 1995). Mayuyama Volcano, located at the easternmost part of Unzen Volcano, comprises 2 huge lava domes of hornblende dacite and 1 pyroclastic flow deposit. As the rifting-induced subsidence in the Unzen graben makes it difficult to positively identify the initial eruption at the surface, and directly observe stratigraphic relation between these eruption products, establishment of the Unzen volcanic history significantly relies on precise chronological control (Table 1 and Figure 4).

\section{3ka Eruptions: Furue L - Kureishibaru PF - Taruki-higashi L}

The Kureishibaru pyroclastic flow deposit of hornblende dacite spreads widely over the northern and northeastern slopes of Fugendake. In site 2, 1 charcoal sample collected inside the Kureishibaru 
${ }^{14} \mathrm{C}$ Dating of Fugendake Volcano in Unzen, SW Japan

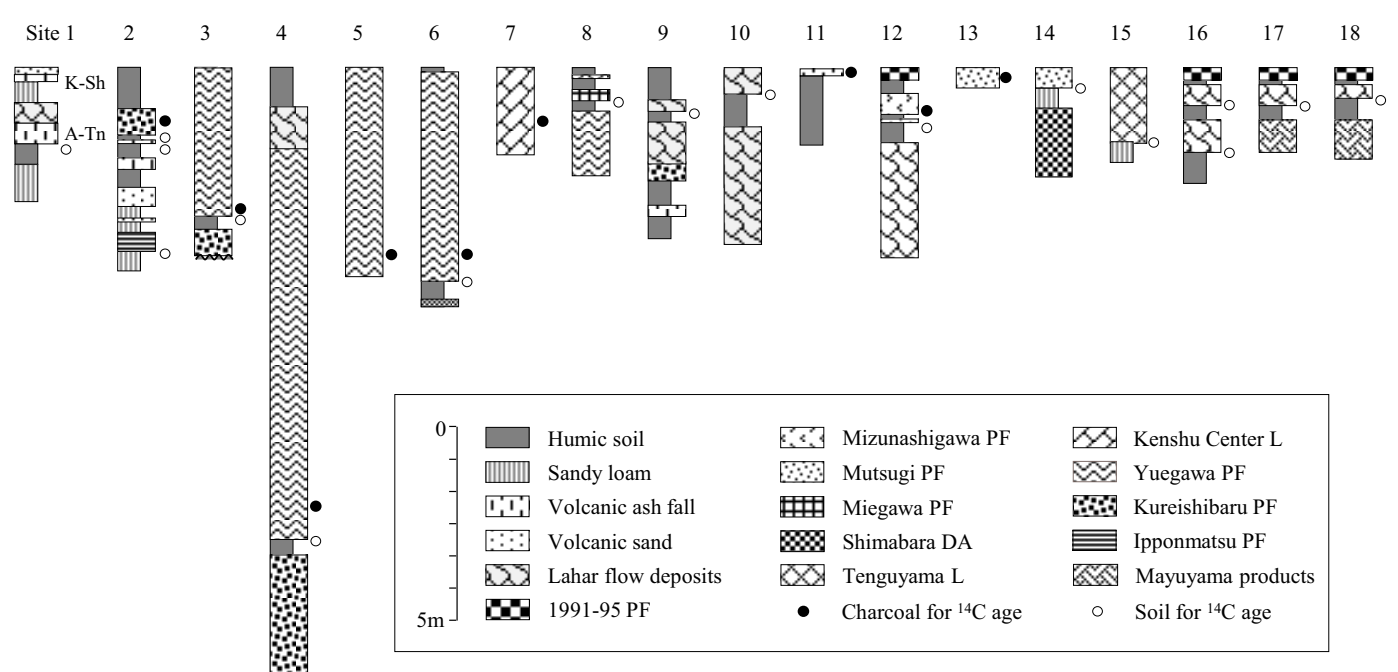

Figure 3 Representative stratigraphic sections around the Fugendake and Mayuyama volcanoes. Sites from 1 to 18 are shown in Figure 2. AT and K-Ah are widespread co-ignimbrite ash-fall deposits from Aira caldera of $29 \mathrm{cal}$ ka BP, and Kikai caldera of $7.3 \mathrm{cal} \mathrm{ka} \mathrm{BP,} \mathrm{respectively.}$

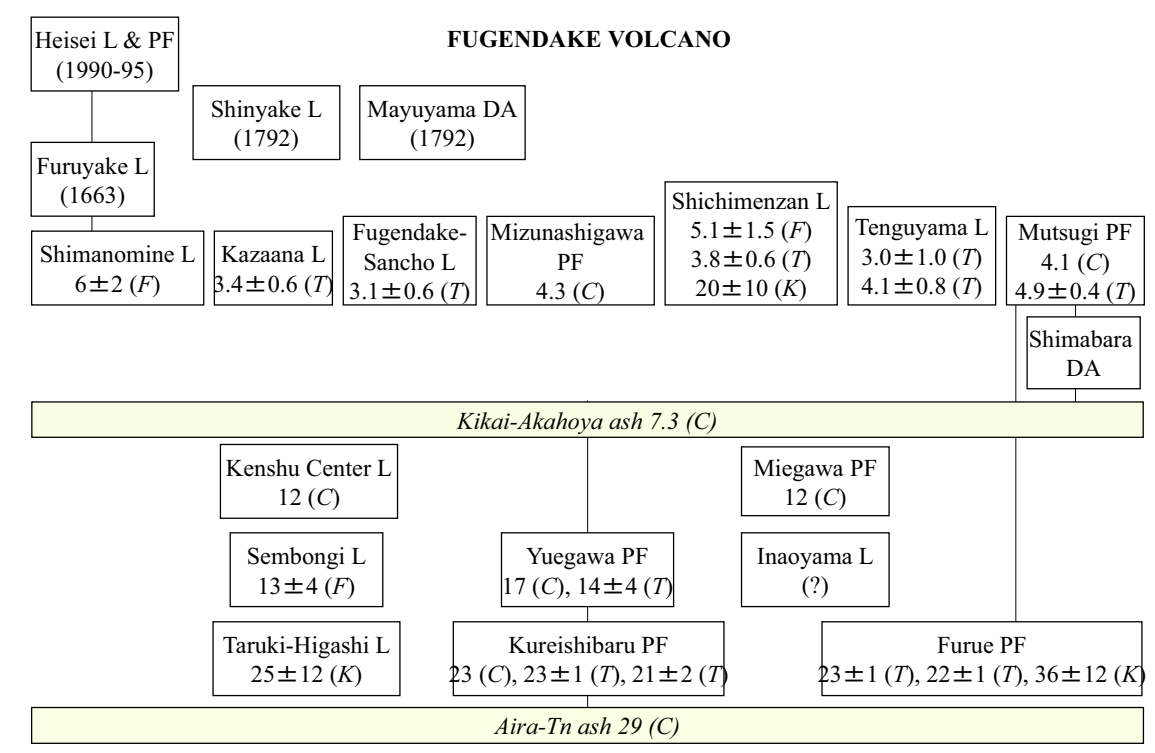

Figure 4 Diagram showing the stratigraphy of the Fugendake and Mayuyama volcanic products. Vertical lines show the stratigraphic relation observed at outcrops. L: lava flow; PF: pyroclastic flow; DA: debris avalanche; C: calibrated ${ }^{14} \mathrm{C}$ age; T: TL age; K: K-Ar age; F: fission track age.

pyroclastic flow gave an age of 18,334 $\pm 134 \mathrm{BP}$ averaged by duplicate analysis (JNC1421 and 1427). This age is consistent with an underlying soil sample whose humin and humic acid fraction ages were 18,390 $\pm 84 \mathrm{BP}$ (JNC1459) and 18,591 $\pm 96 \mathrm{BP}$ (JNC1423), respectively. These ages are consistent with the previous ${ }^{14} \mathrm{C}$ results: $19 \mathrm{ka}$ BP (Kobayashi and Nakada 1991) and 18,850 \pm 180 $\mathrm{BP}$ (Hoshizumi et al. 1999). Moreover, the ${ }^{14} \mathrm{C}$ dates ( $\left.22 \mathrm{cal} \mathrm{ka} \mathrm{BP}\right)$ are comparable with $2 \mathrm{TL}$ ages: $23 \pm 1 \mathrm{ka}$ (Shimao et al. 1999) and $21 \pm 2 \mathrm{ka}$ (Moriyasu et al. 2008). The ${ }^{14} \mathrm{C}$ ages observed at the 


\section{SXu et al.}

surface are also consistent with those measured at USDP1 borehole (Figure 2). The humic soils underlying volcanic-related lahar flow deposits at depth of $56.42 \mathrm{~m}$ of the USDP-1 borehole gave a ${ }^{14} \mathrm{C}$ age of $18.8 \mathrm{ka} \mathrm{BP}$ (Xu et al. 2004), suggesting that the accumulation of the lahar flow deposits was caused by the Kureishibaru pyroclastic eruption.

In the same soil-volcanic stratigraphic sequence in site 2,1 soil sample underlying a thin volcanic ash layer gave an age of 19,220 $\pm 84 \mathrm{BP}$ (humin, JNC1458) and 19,326 $\pm 84 \mathrm{BP}$ (humic acid, JNC1422), slightly older than the overlying Kureishibaru pyroclastic flow deposits. Although the volcanic ash is not sufficiently great, the coeval ${ }^{14} \mathrm{C}$ dates on humic acid and humin fraction and normal stratigraphical relation implied that the closed ${ }^{14} \mathrm{C}$ system may have retained.

Similar to the Kureishibaru pyroclastic flow deposit, the Furue lavas are an andesite block-and-ash flow deposit spread on the southeastern flank of the Fugendake. Hoshizumi et al. $(1995,1999)$ obtained $2 \mathrm{~K}$-Ar ages of $36 \pm 12$ and $67 \pm 14 \mathrm{ka}$, much older than the covering Aira-Tn ash (cal 29 ka). However, 2 consistent TL dates were obtained: $23 \pm 1 \mathrm{ka}$ (Shimao et al. 1999) and $22 \pm 1 \mathrm{ka}$ (Moriyasu et al. 2008). The Taruki-higashi lavas are lava domes of hornblende dacite erupted on the eastern flank of the Fugendake. One K-Ar dating ( $25 \pm 12 \mathrm{ka}$ ) was obtained from the Taruki-higashi lava (Hoshizumi et al. 1995, 1999).

\section{7ka Eruptions: Inaoyama L - Sembongi L - Yuegawa PF}

There are many charcoals in the Yuegawa pyroclastic flow deposits. In site 3, 1 charcoal inside the Yuegawa pyroclastic flow deposits gave an age of 13,699 \pm 78 BP (JNC1427). However, as described above, the sandy loam below the pyroclastic flow showed scattered, young ages, $8899 \pm$ $66 \mathrm{BP}(\mathrm{JNC} 1462)$ and $6629 \pm 59 \mathrm{BP}$ (JNC1428) for humin and humic acid fractions, respectively. In contrast, at site 4,1 charcoal gave a ${ }^{14} \mathrm{C}$ age of $13,650 \pm 64 \mathrm{BP}$ (JNC1424), and humic soil below the pyroclastic flow showed consistent ages of 13,432 $\pm 61 \mathrm{BP}(\mathrm{JNC} 2453)$ and 13,826 $\pm 48 \mathrm{BP}$ (JNC2494) for the humin and humic acid fractions, respectively. In site 5, 1 charcoal gave an age of $13,908 \pm 63$ BP (JNC2449). Similar results can be found in site 6 , where 1 charcoal gave an age of $13,041 \pm 66 \mathrm{BP}$ (JNC2450), and humic soil below the pyroclastic flow showed consistent ages, $14,253 \pm 58 \mathrm{BP}$ (JNC2570) and 13,758 $\pm 59 \mathrm{BP}$ (JNC2704) for the humin and humic acid fractions, respectively. These dates are consistent with a ${ }^{14} \mathrm{C}$ age of $14 \mathrm{ka} \mathrm{BP}$ obtained by Kobayashi and Nakada (1991). Furthermore, these ${ }^{14} \mathrm{C}$ ages are comparable with a TL age of $14 \pm 4$ ka (Moriyasu et al. 2008). The Yuegawa pyroclastic flow age is also comparable with a fission track age of $13 \pm$ $3 \mathrm{ka}$ from the Sembongi lava flow (Danhara et al. 1993). The Senbongi lava is a thick lava flow of hornblende andesite exposed on the flank of the Myokendake. Although there is no date available for the Inaoyama lava yet, these dates seem to collectively suggest that the products at $17 \mathrm{ka}$ had originated from Fugendake Volcano.

\section{2ka Eruptions: Kenshu Center L - Miegawa PF}

In site 7 (Figure 2), a charcoal sample was found in the Kenshu Center lava flow. Duplicate analyses gave ages of 10,454 \pm 55 (JNC1431) and 10,471 $\pm 45 \mathrm{BP}$ (JNC1934), for an average age of 10,462 \pm 36 BP. It should be noted that this lava flow was initially classified into the Older Unzen volcanics based on K-Ar dates (Watanabe and Hoshizumi 1995; Hoshizumi et al. 1999). However, a ${ }^{14} \mathrm{C}$ date obtained here is significantly younger than the upper limit of the Old Unzen volcanics ( $150 \mathrm{ka})$. This finding is compatible with previously published $\mathrm{K}-\mathrm{Ar}$ dates and supported by geological observations. Watanabe et al. (1993) obtained a K-Ar age of $1.33 \pm 0.73 \mathrm{Ma}$ for a hornblende dacite. Duplicate analyses of a hornblende dacite also gave ages of $0.50 \pm 0.35$ and $0.50 \pm 0.38 \mathrm{Ma}$ (Ono et al. 1992). These K-Ar dates are in the range of the Older Unzen volcanics within $1 \sigma$ error margin. 


\section{${ }^{14} \mathrm{C}$ Dating of Fugendake Volcano in Unzen, SW Japan}

However, if using the $2 \sigma$ error margin for the most reasonable consideration, these $\mathrm{K}$-Ar dates are all beyond the determination limit of K-Ar dating and thus suggest ages close to zero. Geological investigations indicated that the W-E-trending Chichiwa fault, one of the major boundary faults of Unzen graben (F1 in Figure 2), disappears in the north of Rokiyama where the Older Unzen volcanics are distributed (Figure 2). This strongly suggests that the Chichiwa fault distributed in the north of Rokiyama should be overlain by younger volcanic products $(<150 \mathrm{ka})$. The age of $10 \mathrm{ka}$ BP obtained from the charcoal thus enabled us to conclude that the Kenshu Center lava flow deposit is a product of the Younger Unzen volcanics. This is also supported by ${ }^{14} \mathrm{C}$ dating of the Miegawa proclastic flow and volcanic-related lahar flow deposits in several adjacent sites. In site 8, a humic soil layer is covered by the Miegawa pyroclastic flow deposits. The humin and humic acid ${ }^{14} \mathrm{C}$ ages are $9833 \pm 51 \mathrm{BP}$ (JNC1460) and 10,036 $\pm 55 \mathrm{BP}$ (JNC1425), respectively. In site 9, the humic soil underlying a volcanic-related lahar flow deposits gave consistent ${ }^{14} \mathrm{C}$ ages for humin, $11,380 \pm 60$ BP (JNC 1704), and the duplicate humic acid 11,284 \pm 49 BP (JNC1699) and 11,331 \pm 50 BP (JNC1708). In site 10, humin and humic acid fractions of burial soil underlying a lava gave similar ${ }^{14} \mathrm{C}$ ages of $10,103 \pm 49 \mathrm{BP}(\mathrm{JNC} 1461)$ and 10,251 $\pm 55 \mathrm{BP}$ (JNC1426), respectively. All these dates indicated simultaneous volcanic products originating from Fugendake Volcano around 10 ka BP (12 cal ka BP).

4.5ka Eruptions: Fugendake-sancho L - Kazaana L - Mizunashigawa PF - Mutsugi PF - Shichimenzan $L$ - Shimanomine $L$ - Tenguyama $L$

At the Fugendake-sancho (summit of Fugendake), the Kazaana and the Shimanomine lavas are composite lava domes of andesite to dacite composition extruded inside the Myokendake scar. The Mizunashigawa pyroclastic flow deposit is also an andesite block-and-ash flow deposit covering part of the SE flank of the Fugendake. These volcanic products were considered to have originated from Fugendake Volcano. However, the Shichimenzan and Tenguyama lavas and Mutsugi pyroclastic flow deposit are isolated from Fugendake Volcano and comprise Mayuyama Volcano.

Yamagata et al. (2004) reported a TL age of $3.1 \pm 0.6 \mathrm{ka}$ from the Fugendake-sancho lava and $3.4 \pm$ $0.6 \mathrm{ka}$ from the Kazaana lava. The Shimanomine lava was dated at $6 \pm 2 \mathrm{ka}$ by the fission-track method (Danhara et al. 1993). Charcoals from the Mizunashigawa pyroclastic flow deposit have been dated to $\sim 4 \mathrm{ka}$ BP by ${ }^{14} \mathrm{C}$ (Kobayashi and Nakada 1991; Ozeki et al. 2005). Our result of a charcoal from the Mizunashigawa pyroclastic flow deposit in site 12 gave an age of $3877 \pm 28 \mathrm{BP}$, comparable with these dates.

Located at the easternmost part of Unzen Volcano, Mayuyama Volcano comprises 2 huge lava domes of hornblende dacite: Shichimenzan and Tenguyama. A zircon fission-track date for the Shichimenzan lava is $5.1 \pm 1.5 \mathrm{ka}$ (Danhara et al. 1993). A K-Ar age of $20 \pm 10 \mathrm{ka}$ was also reported for the Shichimenzan lava (Watanabe et al. 1993). Two TL dates for Shichimenzan and Tenguyama lavas are $3.8 \pm 0.6$ and $4.1 \pm 0.8 \mathrm{ka}$, respectively (Yamagata et al. 2004). The Mutsugi pyroclastic flow deposit is a block-and-ash flow deposit of hornblende dacite derived from the northern part of Mayuyama dome (Hoshizumi et al. 1999). In this study, we obtained a charcoal ${ }^{14} \mathrm{C}$ age of $3762 \pm$ 32 BP (JNC1319) from the Mutsugi pyroclastic flow deposit (site 13), which is significantly younger than the previous results of $4220 \pm 110 \mathrm{yr}$ BP (Hoshizumi et al. 1995) and $4.0 \mathrm{ka} \mathrm{BP}$ (Kobayashi and Kato 1986). Field observations indicated that there are 2 units with different eruption styles, the large block in the upper and a smaller one in the lower unit. No soil layer was observed between the 2 units, which suggests either the condition of unfavorable vegetation growth or a short interval between 2 volcanic episodes. The discrepant ages obtained from this study and previous dates may represent 2 volcanic episodes of the Mutsugi pyroclastic flow deposit. 


\section{SXu et al.}

Mayuyama Volcano was thus active during the building stage of Fugendake Volcano at $4.5 \mathrm{ka}$ and built on the eastern extension of Fugendake. This suggests that magma more felsic than those of Fugendake Volcano was supplied through the same EW-trending extensional fault system, but probably from a different magma reservoir or a more differentiated part of the same reservoir.

\section{Possible Events of Volcanic Eruptions and Lahar Accumulations}

Few pumice deposits were found scattered in the west bank of Mizunashigawa (site 11 in Figure 2). One charcoal was found inside the pumice deposits and ${ }^{14} \mathrm{C}$ dated to $8640 \pm 46 \mathrm{BP}$, or $9.6 \mathrm{cal} \mathrm{ka} \mathrm{BP}$ (JNC2448). If this new date represented a volcanic event, the corresponding eruption would be instantaneous and of limited scale.

There are 2 humic soil layers underlying the lahar deposits (site 16 in Figure 3). The upper soil produced ${ }^{14} \mathrm{C}$ ages of $661 \pm 42 \mathrm{BP}(\mathrm{JNC1468})$ and $633 \pm 58 \mathrm{BP}(\mathrm{JNC} 1436)$ for the humin and humic acid fractions, respectively, while the lower resulted in ages of $1658 \pm 35 \mathrm{BP}$ (JNC1467) and $1668 \pm$ $35 \mathrm{BP}$ (JNC1435). The calibrated ${ }^{14} \mathrm{C}$ age of the upper soil was $610 \mathrm{cal} \mathrm{BP}$ (AD 1340). However, there are no available records to confirm if this event was an unidentified volcanic eruption or a nonvolcanic landslide. The lower soil is comparable with those observed in adjacent sites. In site 17, a soil sample underlain by a lahar deposit was dated with ${ }^{14} \mathrm{C}$ ages of $1712 \pm 37 \mathrm{BP}$ (humin, JNC1470) and $1728 \pm 35$ (humic acid, JNC1438). Another layer of soil nearby (site 19) also produced ${ }^{14} \mathrm{C}$ ages of $1752 \pm 30 \mathrm{BP}(\mathrm{JNC} 1469)$ and $1729 \pm 60 \mathrm{BP}$ (JNC1437) for the humin and humic acid fractions, respectively. More field investigations and dating are needed to clarify if these lahar accumulations were volcanically related.

\section{Outline of the Fugendake-Mayuyama Volcanic History}

Based on the present and previous dates, together with detailed field investigations, the history of the Fugendake-Mayuyame volcanoes can be outlined (Figure 4). Fugendake Volcano erupted mainly within the Myokendake crater. The eruption started about $29 \mathrm{ka}$, probably immediately after the collapse of Myokendake Volcano. The first eruption product is not positively identified, however. Hoshizumi et al. (1999) proposed that it may be the Taruki-higashi lava based on the K-Ar date $(25 \pm 12 \mathrm{ka})$. This hypothesis is supported by ${ }^{14} \mathrm{C}$ ages of a humic soil layer underlying a pyroclastic flow deposit at 71.60-71.90 m depth of the USDP-2 borehole near the Taruki terrace (Figure 2). The topmost soil gave a ${ }^{14} \mathrm{C}$ age of $29 \mathrm{cal}$ ka BP, suggesting the initial activity of Fugendake Volcano (Xu et al. 2004). With the eruptive interval of 5-6 ka, lava flows and lava domes were intermittently produced around 22,17, 12, and $4.5 \mathrm{ka}$ ago, and more recently in AD 1663, 1792, and 1991-1995. Several block-and-ash flows and 1 debris avalanche were accordingly generated by dome collapse processes. On the other hand, Mayuyama Volcano had only 1 simultaneous eruption around $4.5 \mathrm{ka}$ when Fugendake Volcano was active. Hoshizumi et al. (1999) have estimated that the total eruptive volume of Fugendake and Mayuyama is $\sim 3 \mathrm{~km}^{3}$.

\section{CONCLUSIONS}

${ }^{14} \mathrm{C}$ ages of humin and humic acid fractions of a buried humic soil immediately underlying the thick volcanic products appear almost coeval and can represent the eruption or accumulation date. However, sandy loam is not an ideal material to reflect eruptive events. Fugendake Volcano had initiated most likely around 29 ka with large intermittent eruptive events occurring at 22, 17, 12, and $4.5 \mathrm{ka}$, and more recently in AD 1663, 1792, and 1991-1995. Mayuyama Volcano was built around 4.5 ka when Fugendake Volcano was active. 
${ }^{14} \mathrm{C}$ Dating of Fugendake Volcano in Unzen, SW Japan

\section{ACKNOWLEDGMENTS}

We would like to thank A Matsumoto of Geological Survey of Japan for his assistance during field work. S Ito, M Abe, and M Watanabe of JNC Tono Geoscience Center are greatly acknowledged for their assistance during experiments. We are grateful to 2 reviewers for their constructive comments that greatly improved the quality of paper. This study was partially supported by the Unzen Scientific Drilling Project financed by Science and Technology Agency, Japan.

\section{REFERENCES}

Braitseva OA, Sulerzhitsky LD, Litasova SN, Melekestsev IV. 1993. Radiocarbon dating and tephrochronology in Kamchatka. Radiocarbon 35(3):463-76.

Bronk Ramsey C. 2009. Bayesian analysis of radiocarbon dates. Radiocarbon 51(1):337-60.

Danhara T, Iwano H, Hoshizumi H, Watanabe K. 1993. Fission track dating of very young zircon from the Unzen Volcano. Programe and Abstract of Volcanological Society of Japan 2:51. In Japanese.

Goto Y, Gouchi N, Matsuda I. 2011. Radiocarbon dating of the Minamidake debris-avalanche deposit, Shiretoko-iozan volcano, Eastern Hokkaido, Japan. Bulletin of the Volcanological Society of Japan 56: 161-7.

Hamnond AP, Goh KM, Tonkin PJ, Manning MR. 1991. Chemical pretreatments for improving the radiocarbon dates of peat and organic silts in a gley podzol environment: Grahams Terrace, North Westland. New Zealand Journal of Geology and Geophysics 34:18194.

Head MJ, Zhou W, Zhou M. 1989. Evaluation of ${ }^{14} \mathrm{C}$ ages of organic fractions of paleosols from loess-paleosol sequences near Xian, China. Radiocarbon 31(3):680 96.

Hoshizumi H, Uto K, Watanabe K. 1995. K-Ar age determination for Unzen volcano: volcanic history of Unzen volcano. Programe and Abstract of Volcanological Society of Japan 2:99. In Japanese.

Hoshizumi H, Uto K, Watanabe K. 1999. Geology and eruptive history of Unzen volcano, Shimabara Peninsula, Kyushu, SW Japan. Journal of Volcanology and Geothermal Research 89:81-94.

Kobayashi T, Kato W. 1986. Formation history of Unzen volcano. Programe and Abstract of Volcanological Society of Japan 2:77. In Japanese.

Kobayashi T, Nakada S. $1991 .{ }^{14} \mathrm{C}$ ages of pyroclastic flow and avalanche deposits and the history of Unzen volcano. Programe and Abstract of Volcanological Society of Japan 2:140. In Japanese.

Machida H, Arai F. 1983. Extensive ash falls in and around the Sea of Japan from large late Quaternary eruptions. Journal of Volcanology and Geothermal Research 18:151-64.

Martin CW, Johnson WC. 1995. Variation in radiocarbon ages of soil organic matter fractions from late Quaternary buried soils. Quaternary Research 43(2): 232-7.
Madeira J, Monge Soares AM, Brum Da Silveira A, Serralheiro A. 1997. Radiocarbon dating recent volcanic activity on Faial Island (Azores). Radiocarbon 37(2): $139-48$.

Moriyasu M, Okuno M, Takashima I, Nagaoka S, Sakaguchi K, Aizawa J. 2008. Thermoluminescence ages for the Furue, Kureishibaru and Yuegawa pyroclastic flow deposits in the Younger Unzen Volcano, SW Japan. Fukuoka University Science Report. p 53-62. In Japanese with English abstract.

Okuno M. 2002. Chronology of tephra layers in Southern Kyushu, SW Japan, for the last 30,000 Years. Quaternary Research 41:225-36. In Japanese with English abstract.

Okuno M, Nakamura T. 2003. Radiocarbon dating of tephra layers: recent progress in Japan. Quaternary International 105(1):49-56.

Okuno M, Nakamura T, Moriwaki H, Kobayashi T. 1997. AMS radiocarbon dating of the Sakurajima tephra group, Southern Kyushu Japan. Nuclear Instruments and Methods in Physical Research B 123(1-4):470-4.

Okuno M, Nakamura T, Kobayashi T. 1998. AMS ${ }^{14} \mathrm{C}$ dating of historic eruptions of the Kirishima, Sakurajima and Kaimondake volcanoes, Southern Kyushu, Japan. Radiocarbon 40(2):825-32.

Ono K, Watanabe K, Itaya T, Hori S, Hoshizumi H, Hiyashi H, Otsudsuki H. 1992. Geology and K-Ar age of Unzen Volcano (preliminary report). Programe and Abstract of Volcanological Society of Japan 2:1. In Japanese.

Orlova LA, Panychev VA. 1993. The reliability of radiocarbon dating buried soils. Radiocarbon 35(3): 369-77.

Ozeki N, Okuno M, Kobayashi T. 2005. Growth history of Mayuyama, Unzen Volcano, Kyushu, southwest Japan. Bulletin of the Volcanological Society of Japan 50:441-54. In Japanese.

Reimer PJ, Baillie MGL, Bard E, Bayliss A, Beck JW, Blackwell PG, Bronk Ramsey C, Buck CE, Burr GS, Edwards RL, Friedrich M, Grootes PM, Guilderson TP, Hajdas I, Heaton T, Hogg AG, Hughen KA, Kaiser KF, Kromer B, McCormac FG, Manning SW, Reimer RW, Richards DA, Southon JR, Talamo S, Turney CSM, van der Plicht J, Weyhenmeyer CE. 2009. IntCal09 and Marine09 radiocarbon age calibration curves, 0-50,000 years cal BP. Radiocarbon 51(4): 1111-50. 


\section{SXu et al.}

Scharpenseel HW. 1979. Soil fraction dating. In: Radiocarbon dating. In Berger R, Suess H, editors. Proceedings of the 9th International Radiocarbon Conference. Berkeley: University of California Press. p 277-83.

Shimao T, Takashima I, Watanabe K, Izawa E. 1999. Verification of errors and reliability of thermoluminescence age for volcanic rocks -Precise beta-ray correction age of pyroclastic flow deposits of Unzen volcano, SW Japan. Journal of Mineralogy, Petrology and Economic Geology 94(4):109-19. In Japanese with English abstract.

Takashima I, Watanabe K. 1994. Thermoluminescence age determination of lava flows/domes and collapsed materials at Unzen volcano, SW Japan. Bulletin of the Volcanological Society of Japan 39:1-12.

Watanabe K, Hoshizumi H. 1995. Geological map of Unzen volcano $(1: 25,000)$. Geological map of volcanoes 8, Geological Survey of Japan. In Japanese with En- glish abstract.

Watanabe K, Hoshizumi H, Itaya T. 1993. K-Ar ages of Unzen Volcano in Kyusyu, Japan with some aspects of geology of Mayuyama. The Memoirs of the Faculty of Education, Kumamoto University 42:35-41.

Xu S. Zheng G. 2003. Variations in radiocarbon ages of various organic fractions in core sediments from Erhai Lake, SW China. Geochemical Journal 37(1):135-44. Xu S, Hoshizumi H, Ochiai Y, Aoki H, Uto K. $2004 .{ }^{14} \mathrm{C}$ dating of soil samples from the Unzen volcano scientific drilling boreholes. Nuclear Instruments and Methods in Physics Research B 223-224:560-7.

Yamagata T, Takashima I, Watanabe K, Izawa E. 2004. TL dating of new lava domes in Unzen volcano-activities history restoration toward the younger lava dome than 20,000 years. Bulletin of the Volcanological Society of Japan 49:73-81. In Japanese with English abstract. 